\title{
BUSINESS TOURISM IN CHINA. THE CASE OF GUANGZHOU
}

\author{
Silvia IACUONE \\ University “G. d'Annunzio" of Chieti-Pescara, Department of Economic Studies, \\ Viale Pindaro 42, 65127 Pescara, Italy, e-mail: silvia-iacuone@libero.it \\ Luca ZARRILLI* \\ University “G. d'Annunzio" of Chieti-Pescara, Department of Economic Studies, \\ Viale Pindaro 42, 65127 Pescara, Italy, e-mail: luca.zarrilli@unich.it
}

\begin{abstract}
Citation: Iacuone, S., \& Zarrilli, L. (2018). BUSINESS TOURISM IN CHINA. THE CASE OF GUANGZHOU. GeoJournal of Tourism and Geosites, 23(3), 656-667. https://doi.org/10.30892/gtg.23303-317
\end{abstract}

\begin{abstract}
This paper aims at studying the business tourism that affects this economically emerging country, with special regard to the business tourism in Guangzhou (better known as Canton), its influence on urban economy and its relations with other types of tourism. A qualitative-quantitative approach has been used: the qualitative part has been based upon the existing literature and the direct observation of the analysed area, during a field mission of about one month; the quantitative part has been based on related figures. Business tourism represents the primary motivation of inbound tourism in Guangzhou, which is a hot destination for investments, offering considerable business opportunities. Guangzhou is also the Chinese city that hosts the highest number of trade fairs, the most important of which is the "China Import and Export Fair", the biggest Chinese commercial fair. Figures about inbound business tourism flow are not available. Nevertheless, we can assume that business tourism represents the core business of the tourism sector in the city and estimate that the related incoming flow is not less than one million visitors per year.
\end{abstract}

Key words: China, Guangzhou, business tourism, trade fairs, development.

\section{INTRODUCTION TO BUSINESS TOURISM}

Business tourism, considered as one of the most ancient form of tourism (crf. Davidson \& Cope, 2002), has gained increasing importance worldwide in the last decades: more and more travels are made for professional purposes and to create and strengthen economic relationships. According to UNWTO figures, in 2012 business travels accounted for approximately $14 \%$ of all international travels (cfr. Virgil \& Popsa, 2014). Furthermore, as we can see in Figure 1, forecasts for next years are positive. According to Innocenti (2007), we can talk about business tourism when the travel is

\footnotetext{
* Corresponding author
} 
made to carry out a professional activity able to generate an income that is higher than the related expenditures (food, accommodation, transportation etc.). Unlike the leisure segment, in the case of business tourism the tourist services are aimed at companies, bodies, institutions and organizations, in the context of a "B2B" (business-to-business) relationship (Capocchi, 2006). Hence the birth and diffusion of the travel manager, a new corporate executive in charge of selecting travel agencies and tour operators, planning trade agreements with the main suppliers, monitoring the fares applied by carriers, with the goal of reducing the costs for the company without penalizing, but rather improving, the standards of the required services. In parallel, on the supply side, many tour operators are specialising in the business segment or are creating corporate departments specifically addressed to business customers, like the "Business Travel Agencies”, aimed at creating tourist packages for companies.

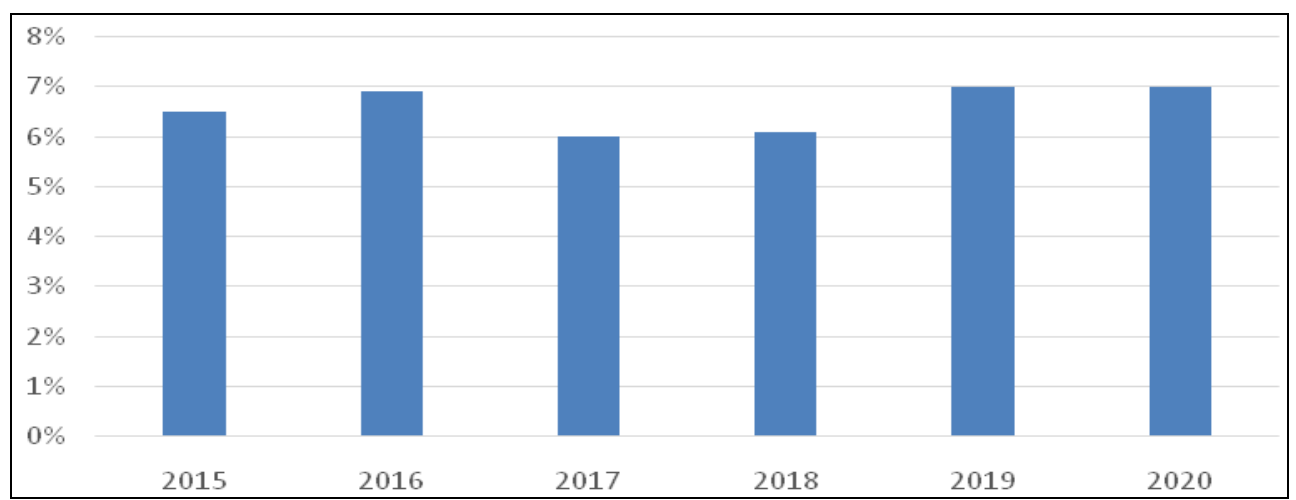

Figure 1. Global business travel spending growth forecast from 2015 to 2020 (Source: www.statista.com)

In general, even if leisure and business segments can use the same means of transport and the same accommodation facilities, there are relevant differences, such as, for example, the clear prevalence of air travels and high level hotels for business travelers. Consequently, the cost of transportation and the average daily spending of a business traveler can be considerably higher than those of a leisure tourist. It also seems that the business segment is more conjunctural, that is more sensitive to the economic trends, if compared to leisure tourism: the financial crisis that occurred in recent years had a negative impact on the tourism sector as a whole, but above all on business travels. It is evident that if the turnovers of the companies decrease, costs for travels and transfers will be the first to be cut. The so-called MICE sub-category (meeting, incentive, conference, event) concerns trips made to attend meetings, congresses, conferences and fairs or for incentive purposes (such as the so called "educational tours"). In fact, there is no professional or industrial association, trade union organization, political party or interest group of any kind that does not organize, even several times during the year, meetings to address specific or general topics.

On the supply side, an increasing number of local authorities have created Convention Bureaus, that are institutional bodies able to act as an interface between the demand (professional and industrial associations, scientific institutions, political parties, trade unions, etc.) and the supply (hotels, airlines, catering companies, interpreting and translation agencies, etc). The Convention Bureaus, moreover, have the task to promote the image of the destination as a favorable MICE location. By the way, adequate facilities are not enough to guarantee the success of the destination, as the customers, which can be particularly demanding, require a whole series of ancillary or complementary services able 
to make the stay as pleasant as possible. Together with business "environment", accessibility, transportation facilities and accommodation capacity and quality, the possibility to enjoy traditional or innovative cultural resources, wellness centres, casinos, shopping areas, sport facilities, etc., in order to match the job with the leisure, is becoming a key element in the choice of the location (Gozner \& Zarrilli, 2012; Gozner, 2015). As it has been noticed, "we note that the factors that influence the choice of the organizers of a location for carrying out certain business events have in view mainly the places with good air links, with a high standard of facilities, which protect the environment and with an attractive image for the business tourist, a tourist with high expectations" (Mureșan et al., p. 1105). In the following chapters, business tourism in China, with special reference to the city of Guangzhou, will be analysed. Actually, in our opinion the city of Guangzhou, thanks to geographical, historical and cultural reasons, possesses all the features necessary to attract investments from the outside, to compete effectively in the business tourism sector and to stand out as one of the most important locations in Southeast Asia for major trade fairs.

\section{METHODOLOGY AND MATERIALS}

To carry on the research, a qualitative-quantitative approach has been used. The research method was firstly supported by the existent literature on the topic (Mok,1985; Martins et al., 2017; Huang \& Chen, 2015; economy and tourism forums and blogs; China National Tourism Administration; Eurostat; UNWTO). Figures on Guangzhou Fair have been mainly supplied by ICE ${ }^{1}$ bureau in Guangzhou. The qualitative part of the research has been realized thanks to a field mission of about a month (from 28.12.2016 to 23.01.2017), aimed at collecting useful documents and figures and having a direct observation of the analysed area, through which it has been possible to get a better understanding of the socio-cultural and economic context of the city of Guangzhou. Locals, functionaries (accommodation facilities, hotels, restaurants, airport, railway station) and public bodies (Guangzhou Immigration Office, Italian Chamber of Commerce in China, Chinese Tourism National Office in Rome) have been questioned, but few answers have been obtained, because of a kind of reticence due to cultural and political reasons.

\section{CHINESE INCOMING TOURISM}

The Chinese model, that the West has tried to domesticate without results, with its about 1,4 billion people and a yearly growing GDP at an average rate of $6,5 \%$, is characterized by a political authoritarianism combined with the liberalization of the economy. Nevertheless, from 1978 to present, policies of economic reforms and of worldwide trade opening have represented one of the most decisive phenomenon of the recent history of China. During this period People's Republic of China underwent deep transformations: both urban and rural societies, ways of living, ways of thinking and behaviors have changed. Economic, financial and business strategies have changed too (Dall'Ara \& Dionisio, 2012). China has opened itself to the rest of the world, and the rest of the world, firstly the West, has looked and continues to look at China in a new way.

Now China is the fourth country in the world as a tourist destination with almost 60 million of international arrivals for leisure or business tourism (UNWTO, 2017), behind France, United States and Spain. The bigger share of tourism is the domestic one that, thanks to a yearly increase of $10 \%$, contributes to the growth of Chinese GDP in the amount of $4 \%$. Nevertheless, the foreign tourism segment shouldn't be underestimated in terms of contribution to the overall growth of Chinese economy, and in particular the flows from Asia and Europe, which represent the main part of inbound tourism.

\footnotetext{
${ }^{1}$ The Italian Trade \& Investment Agency, an agency of Italian Ministry of Economic Development, for the promotion overseas and the globalization of the Italian companies.
} 


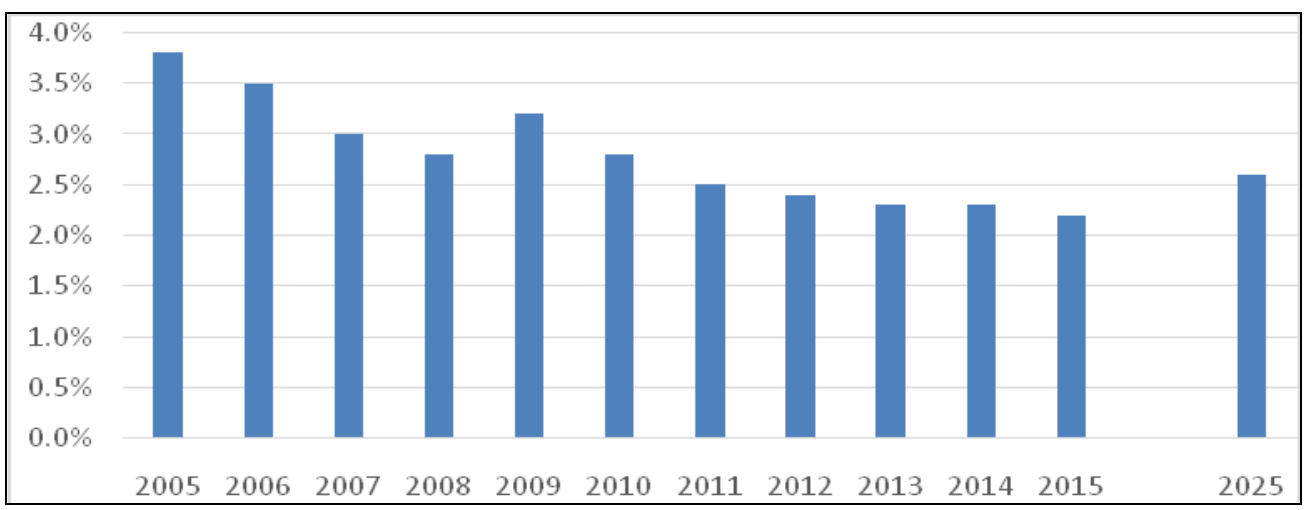

Figure 2. Money spent by foreign tourists as \% of total exports per year (Source: www.wttc.org)

Figure 2 compares the share of money spent by foreign tourists on total exports, which has decreased over time but shows a positive prevision for the near future. Table 1 displays the top 17 countries of origin of inbound tourism in China in 2017.

A pattern of geographical proximity can be observed, with Myanmar, Vietnam, South Korea, Japan and Russia ranking in the first positions. Tourism is becoming increasingly important for China both as a source of revenue and as means to enhance its international image. It is important the way countries leverage their international image to persuade other countries to support their interests. Therefore, it is crucial to assess the global appeal of China and how the Chinese government seeks to cultivate its soft power. Table 1, therefore, gives us come indication about the attractiveness of China as a tourist destination and how Chinese government utilizes tourism as a political tool to foster Chinese interests.

Table 1. Top origin countries of inbound tourism in China in 2017 (\%)

(Source: www.travelchinaguide.com)

\begin{tabular}{|l|c|}
\hline \multicolumn{1}{|c|}{ Countries } & $\%$ \\
\hline 1. Myanmar & 22.5 \\
\hline 2. Vietnam & 15.2 \\
\hline 3. South Korea & 9 \\
\hline 4. Japan & 6.2 \\
\hline 5. Russia & 5.5 \\
\hline 6. USA & 5.4 \\
\hline 7. Mongolia & 4.3 \\
\hline 8. Malaysia & 2.9 \\
\hline 9. Philippines & 2.7 \\
\hline 10. Singapore & 2.2 \\
\hline 11. India & 1.9 \\
\hline 12. Canada & 1.9 \\
\hline 13. Thailand & 1.8 \\
\hline 14. Australia & 1.7 \\
\hline 15. Indonesia & 1.6 \\
\hline 16. Germany & 1.5 \\
\hline 17. UK & 1.4 \\
\hline
\end{tabular}

\section{BUSINESS TOURISM IN CHINA}

A growing country like China is a very good opportunity for a great variety of investments and trade exchanges and it's time to accept that the new global business traveler speaks Chinese as well (Samarani, 2008). The Business and Innovation Blog 
ranks the 12 best opportunities of investments in China, from import-export to healthcare, from green economy to IT, from telecommunications to jewelry etc.

Figure 3 shows that $77,2 \%$ of the total Chinese tourist spending is based on leisure tourism (especially cultural and nature tourism), while the rest $(22,8 \%)$ is represented by business tourism, which is supposed to increase in the future. In table 2 we can see that most of business tourists are from Asia (58\% of the total business tourism in China), because of the geographical proximity, followed by Europe $(25,5 \%)$ and America (10\%). Despite the geographical proximity and the big economic interests, Oceania gives a small contribution to the business tourism flow (2,5\%), because of obvious demographic reasons.

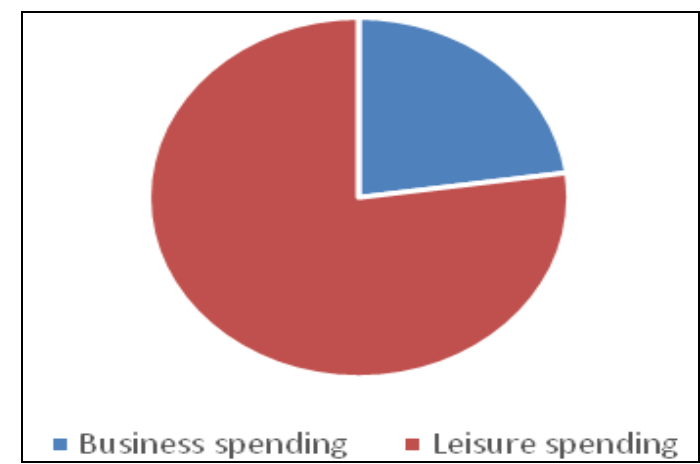

Figure 3. Share distribution in leisure tourism and business tourism spending (Source: www.wttc.org)

Table 2. Foreign arrivals for area of origin in 2015: share on total and business tourism flows (Source: Our elaboration from China National Tourism Administration)

\begin{tabular}{|l|c|c|}
\hline \multicolumn{1}{|c|}{ area } & total tourism flow & total business tourism flow \\
\hline Asia & $64 \%$ & $58 \%$ \\
\hline Europe & $19 \%$ & $25,5 \%$ \\
\hline America & $12 \%$ & $10 \%$ \\
\hline Oceania & $3 \%$ & $2,5 \%$ \\
\hline Africa & $2 \%$ & $4 \%$ \\
\hline Total & $100 \%$ & $100 \%$ \\
\hline
\end{tabular}

On the other side, we can see that Europe and Africa, differently from the other areas, display greater shares of business tourists on the total flow from each area. In the case of Europe, probably it's because of the economic opportunities of this growing country for European firms seeking for investment occasions and cost savings on production factors (labour, raw materials, semifinished products). In the case of Africa, the reasons are presumably different: with a share on total inbound tourism in China of just $2 \%$, Africa contributes to Chinese business tourism to a double extent (4\%). At first sight it could seem a strange value, but actually it finds its origins in the reality of the facts: since at least the last two decades, China has been present on international scene as the biggest developing country of the world and the biggest buyer of strategic raw materials. At the same time Africa, that has the highest number of developing countries, represents in perspective the most important supplier of such materials. It is clear that such new circumstances have created new opportunities for economic and business connections between China and Africa. It is obvious that these two areas are in the right place at the right time: African governments (but not African people) are benefiting from the exploitation of natural resources and China is finding the tools of its development also thanks to this trade exchange. 


\section{TOURISM IN GUANGZHOU: INTRODUCTIVE REMARKS}

The city of Guangzhou, better known as Canton, is on the south-east coast of China, near Hong Kong; it is the ninth most populous city in the world and the third most important city of China after Beijing and Shanghai. Thanks to its strategic position near the Pearl River Delta, the biggest metropolitan conurbation of the world, Guangzhou quickly developed as one of the best port for import-export, becoming the capital of Guangdong Province and, thanks also to its international airport (which is one of the three most important airports of China, listed as one of the first class airports in the world), one of the richest cities of southern China. Guangzhou is different from the other Chinese cities, because of its cultural stratification of symbols and architectures, ranging from monuments of Chinese history to one of the most ancient mosques of China, to remains of Western colonialism. Unlike Beijing and Shanghai, Guangzhou developed step by step. After centuries of degradation caused by overcrowded and unhealthy neighbourhoods, the current structure of the city dates back to the massive rehabilitation which took place in 1920, when a great part of the central ancient walls was demolished and wide avenues and squares were created. Considered for a long time the most polluted and chaotic city of China, in the last decades it has transformed its image into that of a livable one: the quality of life in Guangzhou is now quite good, thanks to the low cost of life, the relatively low level of pollution, the several majestic natural sites and its characteristic culture, consisting in a mix of ancient traditions and futuristic facilities. Thanks to such a duality of old and new features, its international airport, its metro, its high-velocity trains and its symbols (e.g. the Guangzhou Tower, the second highest building of China), Guangzhou is surely a city that looks to innovation without neglecting its traditional culture, and its cuisine in particular. Cantonese cuisine (Figure 4,5 ) is very well known worldwide: in fact, the Chinese cuisine as we known it is the Cantonese one.

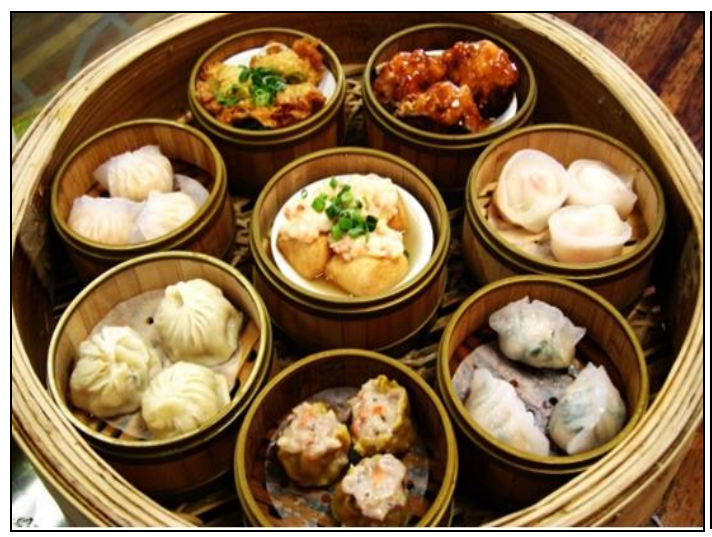

Figure 4. Example of typical Cantonese cuisine

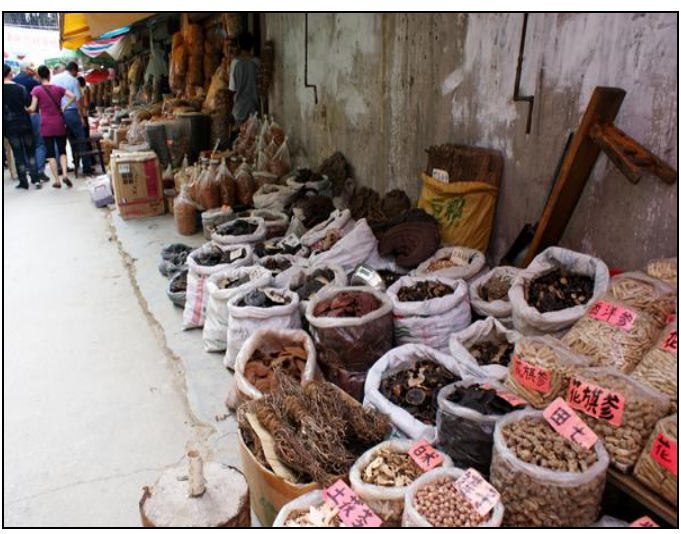

Figure 5. Traditional food open air market

Guangzhou has always been the door of China, for better or for worse; in fact, it used to trade with the West when for Beijing the foreigner was the "devil". Thanks to this openness, the Cantonese area is more developed compared to the rest of the country: in fact, economic liberalization started here. Furthermore, Chinese people that we can find in Europe and in USA comes particularly from Guangzhou (Romano, 2012).

\section{A DIVERSIFIED TOURIST OFFER}

Thanks to its emerging and manifold situation, Guangzhou can attract considerable tourist flows with different motivations and purposes. Actually, Guangzhou is the fifth 
more visited Chinese city by foreign tourists, after the most famous Beijing and Shanghai, and the other two important southern cities of Hong Kong and Macau. As for domestic tourism, from the last decade, Guangzhou is the third most visited city, after Beijing and Shanghai, particularly in the first week of October during the National Holiday and then in the Spring Festival. Guangzhou, in effect, has a very diversified tourist offer, which blends various types of tourism that can be enjoyed in one only travel. This is particularly attracting for the business tourists, who, as stated above, often want to combine job with pleasure, especially in a city like Guangzhou (Figure 6, 7) where they have the possibility to match a job mission with cultural and naturalist experiences.

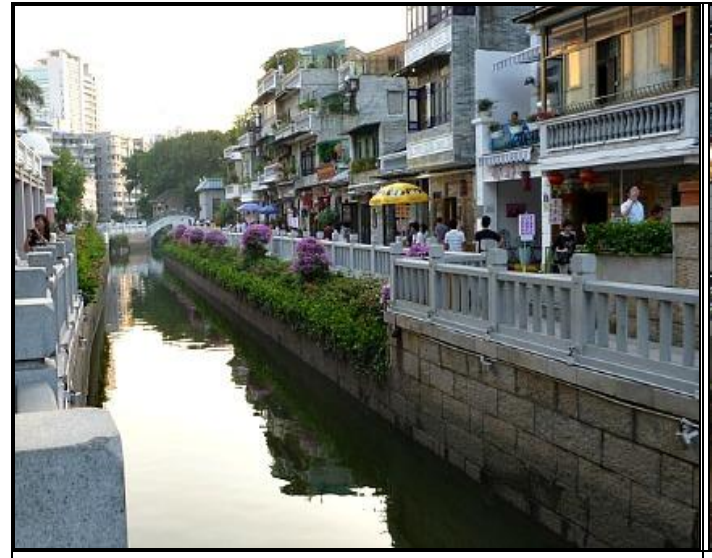

Figure 6. Shangxiajiu Pedestrian Street

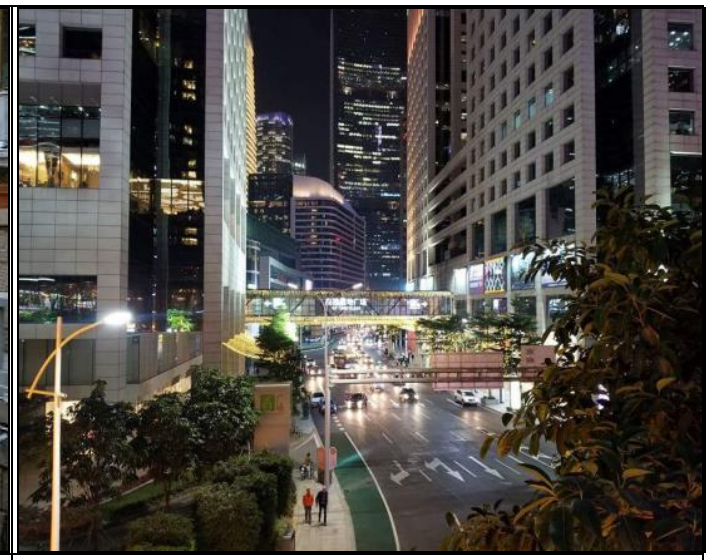

Figure 7. The centre of Guangzhou

Outlined below - with the exception of business tourism, which will be discussed in details in the next chapter - are the main kinds of tourism that this eclectic city has to offer:

- $\quad$ Cultural tourism: Guangzhou is characterized by a contrast between old and new cultural features, ranging from temples and historic sites dating back to $4^{\text {th }}$ century, such as the cultural remains of Chinese Buddhism, to monuments and symbols related to the Maoist period, to modern and westernized buildings and infrastructures. The best examples are: the Temple of the six Banyan Trees, one of the most majestic temples, with its three copper statues of Buddha, among the biggest in Guangdong, that represent past, present and future; the Bright Filial Piety Temple, that is one of the most impressive of China and, according to the legend, existing before the settlement of Guangzhou; commemorative statues like the Guangzhou Liberation Statue, built to commemorate the liberation of the city from Yin Jin Chang and removed by Mao during the Cultural Revolution and then reinstated in 1980, and the Bronze Statue of Dr Sun Yat-Set, that represents an ambitious young man, with two books, one written in Chinese and the other in English, to symbolise his big mental opening. The most important sign of modernity is the Guangzhou Tower (6oo $\mathrm{m})$, the second highest building of China and the fourth in the world. Its strange and asymmetric design symbolises the dynamism of the city. Inaugurated on September $30^{\text {th }}$, 2010 during the Asian Games, it consists of 37 floors that house exhibition centres, a conference centre, a cinema, several restaurants, a panoramic view point and a pedestrian area that is connected to the river (Figure 8,9). The best moment to visit the tower is in the evening, when the river reflects its colorful led lights creating a unique show.

- Nature-based Tourism: Although Guangzhou is a mainly modern and built city, there are various huge green areas, like parks and gardens, that help the city to improve the urban landscape and the air quality. Its majestic mountains, known as "The best beauty 
of Guangzhou", its tropical gardens, its botanical gardens with the rarest species of flowers in the world, the little rivers that, together with the Pearl River, constitute the hydrographic network of the city and that be crossed by small boats, are surely interesting destination for a nature-based tourist motivation. As best examples, we can cite the Baiyun Mountain, known also as "White Clouds"; the South China Botanical Garden, the biggest tropical botanical garden of China, including so many species that it is considered as a botanical museum; another important facility is the Yuntai Garden, known as "the Pearl of Flowers' City" of Guangzhou, the biggest park of this type in all China.

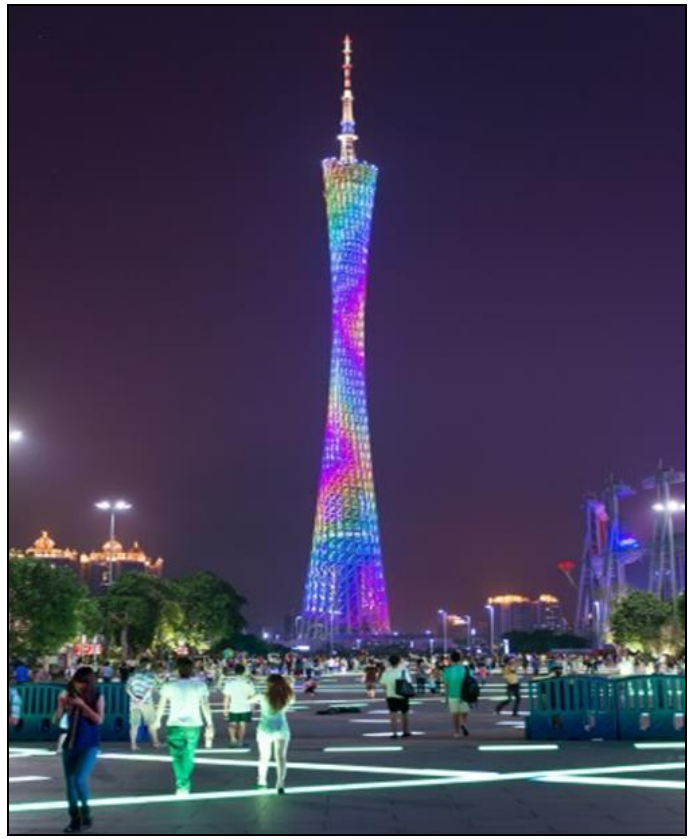

Figure 8. Guangzhou Tower

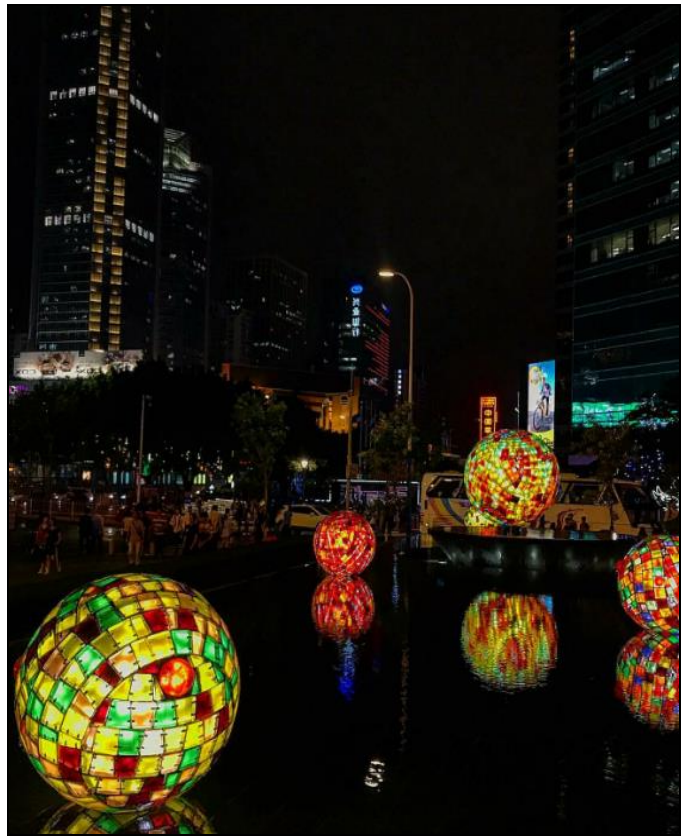

Fig. 9. Evening show on Pearl River

- $\quad$ Sport Tourism: a nice curiosity is about the sport, where we can find great football Italian names. Actually, the city of Guangzhou has a quite good football team. Founded in 1954 with the name "Guangzhou Football Team", it was the first football club in China. In the years it changed various proprietors and names. Between 2010 and 2011, with the denomination of Real Estate Grande, it started to significantly penetrate the football market, also investing abroad. In 2012 the Italian Marcello Lippi was employed as "mister", which led to winning the Chinese Championship and the National Cup, as well as the AFC Champions League in 2013. Later Lippi became technical director, leaving the position of "mister" to Fabio Cannavaro. In the case of Gangzhou and its football team, it is possible to talk about sport tourism, also thanks to the presence as protagonists of some of the most famous Italian champions. Moreover, in 2010 the city hosted the Asian Games, the most important sport show of China. In that occasion the biggest urban reorganization of the city was made, which changed the appearance of Guangzhou thanks to futuristic buildings and a remarkable infrastructural development.

\section{BUSINESS TOURISM IN GUANGZHOU}

Business tourism represents the beating heart and the primary motivation of inbound tourism in Guangzhou. Today Guangzhou is the economic, political, scientific and cultural 
centre of southern China, and is also the third most important city of China after Beijing and Shanghai. It has very modern infrastructures, 9 metro lines, several train stations that link city with the rest of the country (also thanks to high speed lines), a very important international airport, a majestic and enormous modern exhibition centre and a futuristic business centre. As already said, it is a very dynamic city, quite open to the West, as well as a commercial hub with an excellent transport network and high level infrastructures, including its port, which ranks fourth in China for the import-export of each type of goods: "Today, thanks to its strategically-placed location, it has sea connections to over 300 ports in more than 80 countries all over the world" (Icontainers, 2018). Moreover, the city has some dedicated areas for commercial and productive settlements: Guangzhou Economic \& Technological Development District; Guangzhou Hi-Tech Industrial Development Zone; Guangzhou Export Processing Zone; Guangzhou Free Trade Zone. It is a hot destination for investments, offering considerable business opportunities. As a matter of facts, since 2015 companies from more than 130 countries invested in Guangzhou, in several sectors, such as manufacturing, services, transports, finance, technology, trade. In figure 10 the share distribution of foreign investments in Guangzhou area by origin is represented. Excluding Hong Kong, which has now returned under Chinese sovereignty with a special economic status, the biggest share comes from a group of countries defined as "Relevant Islands", formed mainly by United Kingdom and some tax havens, followed by Japan and Singapore.

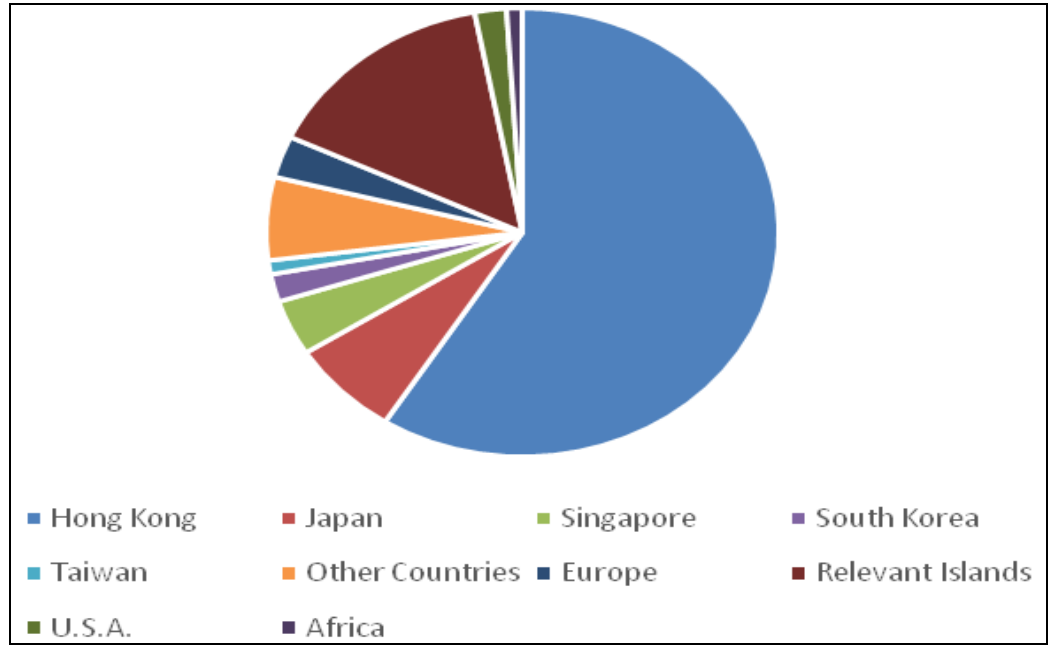

Figure 10. Share distribution of foreign investments by origin (Source: Guangzhou International)

Since 2007 the Bureau of Foreign Trade and Economic Cooperation of Guangzhou Municipality is promoting the urban economy, also by publishing the so-called "white paper", which illustrates the main macro-economic data about the city. In table 3 the main data related to 2015 are displayed.

Guangzhou is also the Chinese city that hosts the highest number of trade fairs (e.g.: the fairs of clothing, industry, home décor, food, technology, manufacturing etc.), the most important of which, from the economic and commercial points of view, is the "China Import and Export Fair" (Canton Fair), instituted in 1957. In 2008 the Canton Fair has been transferred in the new modern exhibition centre of Pazhou, in southeastern Guangzhou. The fair takes place each year in two sessions (spring and autumn) and is the biggest Chinese commercial fair with the most extended array of products, the highest number of exhibitors and visitors, both Chinese and foreigners, the biggest exhibition 
area and the highest number of concluded sale contracts. Actually, this fair concerns every kind of item, equipment and machinery produced in China. It has a gigantic size, with its 630.000 square meters of exhibition space, 25.000 exhibitors, 30.000 stands, about 400.000 visitors and a yearly business volume that exceeds 60 billion dollars.

Table 3. Main macro-economic data about Guangzhou in 2015 (Source: Guangzhou International)

\begin{tabular}{|l|c|}
\hline Index & Year-on-year growth (\%) \\
\hline Gross Domestic Product (GDP) & $8,4 \%$ \\
\hline Gross Value of Industrial Output & $6,4 \%$ \\
\hline Added Value of Industrial Enterprises & $7,2 \%$ \\
\hline Fixed Asset Investment & $10,6 \%$ \\
\hline Total Retail Sales of Consumer Goods & $11,0 \%$ \\
\hline Import & $3,5 \%$ \\
\hline Export & $12,7 \%$ \\
\hline Actual Foreign Investment & $6,1 \%$ \\
\hline Investment by Chinese Companies in overseas investment & $30,4 \%$ \\
\hline Service Trade & $14,5 \%$ \\
\hline
\end{tabular}

With sales representatives from various countries and sectors, no doubt it is the most important, functioning, diversified and popular import-export fair in China. There are international commercial societies, research laboratories, industries of all sectors and firms established in China (with Chinese, mixed or foreign capital), as well as multinational corporations. Thanks to the presence of thousand of firms, the Canton Fair is the starting point for the firm that wants to trade with China, particularly in the electronics, light industry and textile sectors. At the same time it represents a way to deal with technical collaboration, transport, insurance, publicity, consultancy, but also a way to take contacts with potential suppliers or clients in view of future investments or to maintain a network of contacts, which is a central element of any international economic activity. During a field research hindered by reticence and scarce collaboration on the part of the Chinese institutional bodies, we were supplied by ICE, and in particular by ITA office, Italian Trade Agency, located in Guangzhou, with data on the fair (processed by Canton Fair). The fair takes place each year in two sessions (spring and autumn) and is the biggest Chinese commercial fair with the most extended array of products, the highest number of exhibitors and visitors, both Chinese and foreigners, the biggest exhibition area and the highest number of concluded sale contracts.

Table 4. Data on Guangzhou Fair per decade from 1960 to 2010 (Source: www.cantonfair.org.cn)

\begin{tabular}{|c|c|c|c|}
\hline year & \multicolumn{3}{|c|}{ number of buyers } \\
\hline & spring session & autumn session & total \\
\hline 1960 & 2.688 & 2.542 & 5.230 \\
\hline 1970 & 7.290 & 8.046 & 15.336 \\
\hline 1980 & 20.560 & 21.959 & 42.519 \\
\hline 1990 & 40.436 & 42.236 & 82.672 \\
\hline 2000 & 98.005 & 105.031 & 203.036 \\
\hline 2010 & 203.996 & 200.612 & 404.608 \\
\hline
\end{tabular}

Actually, this fair concerns every kind of item, equipment and machinery produced in China. It has a gigantic size, with its 630.000 square meters of exhibition space, 25.000 exhibitors, 30.000 stands, about 400.000 visitors and a yearly business volume that exceeds 60 billion dollars. Table 4 shows a remarkable increase of buyers over the decades from 1960 to 2010 (from about 5.000 to more than 400.000 ). It can also be seen that the growth is 
quite regular until 2010, with the number of buyers doubling - or more than doubling - at every decade, which is the sign of a country that, step by step, opened itself to the rest of the world and attracted investors and commercial partners worldwide at a growing pace.

Table 5. Data on Guangzhou Fair per year from 2011 to 2017 (Source: www.cantonfair.org.cn)

\begin{tabular}{|c|c|c|c|c|}
\hline year & \multicolumn{3}{|c|}{ number of buyers } & business turnover (bn $\$$ ) \\
\hline & spring session & autumn session & total & \\
\hline 2011 & 207.103 & 209.175 & 416.278 & 74.760 \\
\hline 2012 & 210.000 & 188.145 & 398.145 & 68.710 \\
\hline 2013 & 202.766 & 189.646 & 392.412 & 67.230 \\
\hline 2014 & 188.119 & 186.104 & 374.223 & 60.211 \\
\hline 2015 & 184.801 & 177.544 & 362.345 & 55.066 \\
\hline 2016 & 185.596 & 185.704 & 371.300 & 55.974 \\
\hline 2017 & 196.490 & 191.950 & 388.440 & 60.180 \\
\hline
\end{tabular}

Table 5, however, shows a significant decrease both in terms of buyers and business turnover between 2012 and 2015, probably as a consequence of the global financial crisis, that inevitably had repercussions also on Chinese economy, even if to a lesser extent than many other countries. Since 2016, however, an upswing is taking place, possibly a symptom of a global economic recovery. The above-mentioned data are in fact very meaningful and confirm the importance of business tourism for Guangzhou, no doubt the most significant type of tourism for the city. Unfortunately, related figures are not available. Nevertheless, an estimate of the order of magnitude of this phenomenon can be done: with about 400.000 buyers and about 25.000 exhibitors spending at least 2 nights in accommodation facilities, we approach a yearly value of about 1 million overnight stays just for the "China Import and Export Fair", which is only one - even if the most important - of the many fairs that take place in Guangzhou every year. It's reasonable to assume that the total figure is much higher, so much so as to represent the core business of the tourism sector in the city and an outstanding source for the urban economic development.

\section{CONCLUSIONS}

Business tourism has gained in the last decades increasing importance worldwide. According to UNWTO figures, in 2012 business travels accounted for approximately 14\% of all international travels, and forecasts for next years are positive. In the case of China, this percentage is even higher, because of the economic opportunities offered by this growing country: $22,8 \%$ of the total inbound flow is represented by business tourism, which is supposed to increase of $4,9 \%$ in the 2025. In the context of Chinese urban network, the city of Guangzhou (also known as Canton) occupies an important place: on the south-east coast of China, in a strategic position near the Pearl River Delta, Guangzhou quickly developed as one of the best port for import-export. Thanks to a fascinating mix of old and new features, its international airport, its metro, its highvelocity trains and its symbols (e.g. the Guangzhou Tower, the second highest building of China), Guangzhou is surely a city that looks to innovation without neglecting its traditional culture. Thanks to its emerging and manifold situation, and to a diversified tourist offer, Guangzhou attracts considerable tourist flows with different motivations and purposes. This is particularly attracting for the business tourists, who often want to combine job with pleasure. Business tourism, actually, represents the primary motivation of inbound tourism in Guangzhou, which is a hot destination for investments, offering considerable business opportunities: since 2015 companies from more than 130 countries invested in Guangzhou in several sectors, such as manufacturing, services, transports, 
finance, technology, trade. Even more important, Guangzhou is also the Chinese city that hosts the highest number of trade fairs, the most important of which is the "China Import and Export Fair", the biggest Chinese commercial fair with the most extended array of products, the highest number of exhibitors and visitors, the biggest exhibition area and the highest number of concluded sale contracts, with about 400.000 buyers, 25.000 exhibitors and a business turnover of more than 60 billion dollars.

Unfortunately, figures about inbound business tourism flow are not available. Nevertheless, we can assume that business tourism represents the core business of the tourism sector in the city and an outstanding source for the urban economic development.

\section{REFERENCES}

Capocchi A. (2006). Elementi di management per l'azienda turistica [Elements of Management for the Tourist Company], Edizioni Plus, Pisa.

Dall'Ara G., \& Dionisio P. (2012). Come accogliere i turisti cinesi. Introduzione alle relazioni con il mercato turistico più grande del mondo [How to welcome Chinese tourists. Introduction to relations with the biggest tourist market of the world], Franco Angeli, Milano.

Davidson, R., \& Cope B. (2002). Business Travel: Conferences, Incentive Travel, Exhibitions, Corporate Hospitality and Corporate Travel, Financial Times/Prentice Hall, Upper Saddle River.

Gozner, M., \& Zarrilli, L. (2012). Types and forms of tourism in the Albac - Arieşeni territorial system (Alba county, Romania), GeoJournal of Tourism and Geosites, YearV,no.1,vol.9, Oradea-Gdansk, Ed. Universităţii din Oradea;

Gozner, M. (2015). Solutions for the development of leisure tourism by specific arrangements in the Albac Arieşeni territorial system, GeoJournal of Tourism and Geosites, Year VIII, Volume 15, Oradea-Gdansk, Ed. Universităţii din Oradea.

Huang, S., \& Chen, G. (2015). Tourism Research in China: Themes and Issues, Channel View Publications, Bristol.

Innocenti P. (2007). Geografia del Turismo [Tourism Geography], Carocci, Roma.

Martins L.F., Gan Y., \& Ferreira-Lopes A. (2017). An empirical analysis of the influence of macroeconomic determinants on World tourism demand, in Tourism management, vol. 61, pp. 248-260.

Mok H., (1985). Tourist expenditures in Guangzhou, PR China, in Tourism management, vol. 6, issue 4, pp. $272-279$.

Mureşan M.L., Chiripuci B.C., \& Nistoreanu, P. (2017). Business tourism - a sustainable form to relaunch Romanian tourism, Proceedings of the 11th International Conference on Business Excellence, vol. 11, issue 1, De Gruyter, pp. 1101-1110.

Romano L. (2012). Cina, tra Pechino e Canton la linea ad alta velocità più lunga del mondo [China, the longest high speed line of the world between Beijing and Guangzhou], Il Giornale, 26.12.2012.

Samarani G. (2008). La Cina del Novecento. Dalla fine dell'Impero ad oggi [China of the Twentieth Century. From the end of the Empire till today], Einaudi, Torino.

Virgil N., \& Popsa R.E. (2014). Business Tourism Market Developments, Procedia Economics and Finance, n.16, pp. $703-712$.

Zarrilli L. (2007). Nuovi orizzonti globali: il turismo cinese [New global developments: Chinese tourism], in Landini, P. (ed.), Turismo e territorio, L'Italia in competizione [Tourism and territory, Italy in competition], Società Geografica Italiana, Roma, pp. 34-35.

*** Business and Innovation Blog, www.laowaicareer.com.

***Canton Fair, www.cantonfair.org.cn.

*** China National Tourism Administration, http://en.cnta.gov.cn.

*** Chinafolio, http://www.chinafolio.com.

*** Chinapower, www.chinapower.csis.org.

*** Eurostat, http://ec.europa.eu/eurostat.

*** Guangzhou International, http://english.gz.gov.cn.

*** ICE institute, http://www.ice.gov.it.

*** Icontainers, http://www.icontainers.com/us/2018/01/16/top-10-ports-in-china/.

*** Statista. The Statistics Portal, www.statista.com.

*** Travel China Guide, www.travelchinaguide.com

*** UNWTO, Tourism Highlights, 2017 Edition, http://www2.unwto.org/ca/node/49151.

*** World Tourism Organization, http://www.world-tourism.org.

*** World Travel and Tourism Council, http://www.wttc.org.

Submitted:

21.06.2018
Revised:

01.10.2018
Accepted and published online 04.10.2018 